\title{
Noncarious Cervical Lesions: Correlation between Abfraction and Wear Facets in Permanent Dentition
}

\author{
Felice Femiano*, Rossella Femiano, Luigi Femiano, Vincenzo Maria Festa, \\ Rosario Rullo, Letizia Perillo \\ Multidisciplinary Department of Medical-Surgical and Dental Specialties, Second University of Naples, \\ Naples, Italy \\ Email: ${ }^{*}$ femiano@libero.it
}

Received 16 May 2015; accepted 27 June 2015; published 30 June 2015

Copyright (C 2015 by authors and Scientific Research Publishing Inc.

This work is licensed under the Creative Commons Attribution International License (CC BY). http://creativecommons.org/licenses/by/4.0/

(c) (i) Open Access

\begin{abstract}
Non-carious cervical lesions (NCCLs) are defined as the loss of dental hard tissue at the cementenamel junction. Erosion, abrasion, and attrition have been associated with this disorder. Objective: Recently, occlusal stress causing of cervical enamel cracks (abfraction) has been considered as an additional etiology for NCCLs to facilitate the erosion and abrasion mechanisms in tooth wear. Study Design: The prevalence of NNCLs and wear facets in a population with permanent dentition in absence of any clear etiological factors related to erosion and abrasion causes is evaluated. $A$ total 295 subjects are enrolled for this study and divided into four age groups (subjects aged 15 27 years, 28 - 42 years, 43 - 57 years and 58 - 75 years respectively). An overall of 6629 teeth are investigated to find NCCLs and wear facets. The occlusion is analyzed in each patient. Results: An overall of 801 teeth (12\%) show NCCLs and 623 of them (78\%) highlight also wear facets. The higher number of teeth with NCCLs and of these with simultaneous presence also of wear facets are found on teeth of patients of group-3 (11\% of all teeth examined for group and $81 \%$ respectively) and to group-4 (24.4\% of all teeth examined for group and $\mathbf{8 6 . 5 \%}$ respectively) of remaining teeth without NCCLs (5828) only 138 (2.4\%) shown wear facets. Conclusion: The results of this study held the occlusal forces as the main cause of NCCLs on teeth in presence of wear facets.
\end{abstract}

\section{Keywords}

Abfraction, Bruxism, Occlusal Stress, Noncarious Cervical Lesion, Wear Facet

\footnotetext{
${ }^{*}$ Corresponding author.
}

How to cite this paper: Femiano, F., Femiano, R., Femiano, L., Festa, V.M., Rullo, R. and Perillo, L. (2015) Noncarious Cervical Lesions: Correlation between Abfraction and Wear Facets in Permanent Dentition. Open Journal of Stomatology, 5, 152-157. http://dx.doi.org/10.4236/ojst.2015.56021 


\section{Introduction}

The term noncarious cervical lesion (NCCL) refers to the loss of tooth structure at the cemento-enamel junction (CEJ) and subjacent root surface of the teeth by wear processes unrelated to bacterial action [1]. The lesions can be located on the vestibular, oral, or approximal side of the tooth. NCCLs may cause problems such as poor aesthetics, increased plaque retention, tooth sensitivity compromising the pulp vitality, and can be diagnosed by detailed history, visual, and tactile examination [2]. NCCLs are managed by addressing any identifiable underlying causes, the application of desensitizing agents, and the placement of restorations, but prevention and management can be difficult if their etiology is unclear [3]. The prevalence of cervical wear attributed to noncarious processes is reported to fluctuate between $5 \%$ and $85 \%$ of all the pathological destructions of the hard dental tissue [4]. This large variation reflects the relatively few studies reporting the prevalence of cervical wear alone. Abrasion, erosion and corrosion are considered as the causes of NCCLs, and often the lesion shape is related to its etiology [5]. Levitch et al. (1994) suggested that dental cervical lesions with sharply defined margins could be caused by abrasion factors, whereas erosive causes could produce broader, dish-shaped, and shallower lesions [4] [6]. Lee et al. (1984) and Oginni et al. (2003) disagreed that excessive or incorrect brushing could be responsible for wear of hard tissue of the teeth. This is especially true when only a single tooth is involved or when NCCLs are found in patients who have never brushed teeth [7] [8]. In fact, the finding of a tooth with a NCCL adjacent to a tooth without any lesions, the presence of subgingival non carious lesions where it should not occur, owing to erosion or abrasion factors, and the occurrence of wedge-shaped lesions in animal teeth and in the teeth of prehistorical people, have strengthened the hypotheses that different etiological factors for NCCLs can operate [9].

Grippo (1991) introduced a new category, abfraction from the Latin words "ab" or away and "fractio" or breaking to explain NCCLs. The abfraction hypothesis is a biomechanical theory in which tensile stress concentrations at the cervical regions of the teeth, caused by tooth flexure during heavy occlusal loading, leads to cervical micro-crack formation by disrupting bonds between hydroxyapatite crystals in enamel and dentine. This will allow the water or other small molecules to penetrate the broken hydroxyapatite chemical bonds making the tooth susceptible to chemical erosion or less resistant to abrasive factors [10]. The discovery of well-demarcated and flattened shiny areas on the chewing surfaces of the teeth, known as wear facets, can reveal a stressful occlusion by tooth-tooth interaction [11]. The finding of wear facets in teeth with wedge-shaped NCCLs should give more validation to occlusal stress as causative agent and in some cases should be considered as the initial event in absence of other recognizable causative factors [12]. Because the prevalence of NCCLs is increasing, the identification of the risk factors intercepting the initial trigger represents the key for success in diagnosis, prevention, treatment and management of cervical lesions. The aim of this study is to evaluate the etiological responsibility of occlusal stress in teeth with wedge-shaped NCCLs, in absence of etiological factors correlated to abrasion or erosion, analyzing the contemporaneous presence of wear facets in a population with permanent dentition.

\section{Subjects and Methods}

A total of 878 patients (aged 6 - 78 years, median 54 years) came to the Department of Dentistry at the Second University of Naples between 2009 and 2014 complaining of dental problems. All patients were informed of the purpose of the research and on the details of the examination procedures.

Only one dental researcher was utilized to examine all patients. The buccal, lingual, and palatal surfaces of all of the teeth were examined with probe tips utilizing measuring glasses at $\mathrm{x} 4$ magnification. The tip of the probe was held perpendicular to the tooth surface and inserted to the bottom of the gingival sulcus, crossing the cement-enamel junction (CEJ). If the probe detected some irregularity, to cervical enamel and at the CEJ of the teeth, these were considered noncarious cervical lesions [13]. Afterward, the lesions hidden in the depth of the gingival sulcus were revealed by a gingival retraction cord. All lesions were photographed and analyzed using a computer graphics software to better identify the shape and angles of NCCLs.

Patients satisfying the following criteria were considered suitable for the study:

—age older than 14 years;

- presenting with a wedge or V-shaped vestibular or palatal/lingual lesions at the cervical enamel and at the CEJ of at least 1 tooth.

Exclusion criteria 
Patients with a history of tooth abrasion and erosion:

- excessive brushing of teeth correlated with a history of toothbrush renewal, in less than 30 days for medium bristles and 45 days in for hard bristles, for premature curvature of the bristles becoming curled and matted;

- use of excessive abrasive toothpaste with relative abrasive dentine $(\mathrm{RDA})>120$;

-reported history of horizontal brushing of teeth (toothbrush abrasion);

—a usual diet of acidic foods, soft drinks, alcoholic beverages, fizzy mineral water, or fruit juice;

- gastro-esophageal reflux or anorexia;

-habitual use of tranquilizers for more than two months.

On the basis of these criteria, 295 patients (130 males and 165 females; aged 15 to 75 years, mean 54 years) were enrolled in this study. All patients signed an informed consent form, and the procedures of this study were in accordance with institutional and national ethical standards on human experimentation and the Helsinki Declaration of 1975, as revised in 2008. For these subjects, 6629 permanent teeth were examined (with a mean of 22 teeth per subject) and grouped by type as shown in Table 1 . Teeth with prosthetic hooks and with structural abnormalities showing NCCLs were excluded from study.

In all patients, bruxism activity, and occurrence of dental attrition and occlusal pits checking dental occlusion during both centric function and lateral excursion and protrusion were analyzed. The cervical lesions were examined, and the occlusal contacts in maximal intercuspal position (MIP) and during lateral and protrusive movements with the aid of articulation paper were verified. The presence of wear facets for all affected and unaffected teeth by NCCLs in MIP and during lateral and protrusive movements was investigated visually after careful drying of teeth. The wear facets were assessed for identification of flat and smooth surfaces on the cusp ridges, on triangular ridges, or on inclined planes of the examined teeth and validated by find of similar wear facets in correspondence of surfaces of opposed teeth with help of articulating paper. All data obtained from this study were analyzed by Chi square Test.

\section{Results}

The patients were divided into four age groups: group- 1 with subjects of 15 - 27 years, group-2 of 28 - 42 years, group-3 of 43 - 57 years, and group-4 of 58 - 75 years. A total of 801 teeth were found affected by V-shaped

Table 1. V-shaped NCCLs assigned for type of teeth and presence of wear facets on teeth with V-shaped NCCLs.

\begin{tabular}{cccc}
\hline Different types of teeth & Teeth examined & Teeth with NCCLs & teeth with NCCLs and Wear facets \\
\hline Maxillary incisors & $\mathrm{n}(\%)^{*}$ & $\mathrm{n}(\%)^{* *}$ & $\mathrm{n}(\%)^{* * *}$ \\
Mandibular incisors & $966(14.6)$ & $100(10)$ & $78(78)$ \\
Maxillary canines & $955(14)$ & $121(13)$ & $65(76)$ \\
Mandibular canines & $496(7.5)$ & $84(17)$ & $56(76)$ \\
Maxillary premolars & $493(7.4)$ & $77(16)$ & $112(81)$ \\
Mandibular premolars & $980(14.8)$ & $139(14)$ & $98(83)$ \\
Maxillary molars & $961(14.5)$ & $118(8)$ & $64(75)$ \\
Mandibular molars & $887(13.4)$ & $85(10)$ & $56(73)$ \\
T Test & $891(13.4)$ & $77(9)$ & $\mathbf{3 1 8}$ \\
Total maxillary & & & $\mathbf{3 1 0})$ \\
Total mandibular & $\mathbf{3 3 2 9}$ & $\mathbf{4 0 8}$ & $\mathbf{3 0 5}$ \\
Total & $\mathbf{3 3 0 0}$ & $\mathbf{3 9 3}$ & $\mathbf{6 0 1}(\mathbf{1 2})$ \\
Total patients & $\mathbf{6 6 2 9}$ & $\mathbf{2 9 5}$ & $\mathbf{2 4 3}$ \\
\hline
\end{tabular}

*Percentage of examined teeth for type; **Percentage of teeth with V-shaped NCCLs in relation to total teeth examined for type; ***Percentage of teeth with wear facets on teeth with V-shaped NCCLs for each category. 
A total of 801 teeth were found affected by V-shaped NCCLs, of which, 408 in the maxilla and 393 in the mandible. The number of lesions per subject ranged from 1 to 15 , with a mean of 2.72 lesions per subject. Table 1 shows teeth with NCCLs grouped for type of teeth. Only 243, of 295 subjects examined, showed 623 teeth with wear facets on teeth with NCCLs. The distribution of teeth with NCCLs in 4 age groups has allowed the evaluation of the morbidity of NCCLs and of wear facets in the examined teeth in relation to age. The higher prevalence/incidence of NCCLs highlighted on teeth for each group and of which those with simultaneous presence of wear facets were found in subjects of group-3 (11\% and 81\% respectively) and of group-4 (24.4\% and 86.5\% respectively) (Table 2). Besides we highlighted a total of 382 anterior teeth and 419 posterior teeth with NCCLs without wear facets vs a total 293 anterior teeth and 330 posterior teeth with simultaneous presence of NCCLs and wear facets.

The 623 total teeth with simultaneous presence of NCCLs and wear facets were found in 114 subjects showing evident or referred parafunctional habits (such as bruxism, nail biting), in 21 with chewing unilaterally, in 31 with clenching of teeth and in 47 with tooth malposition; only 30 subjects did not show any clear parafunctional activity or occlusal abnormalities. The rest of 178 teeth with NCCLs without wear facets ( $2.7 \%$ of 6629 of total teeth; $22 \%$ of 801 total teeth with NCCLs) were found in patients with positive medical history for parafunctional habits or activity but belonged to younger groups for which, probably, the time had not yet allowed the formation of wear facets.

Besides the study highlighted the presence of 138 teeth with wear facets without NCCLs (Table 3).

\section{Discussion}

Of the 6629 teeth analyzed in 295 subjects, 801 teeth (12\%) showed V-shaped NCCLs and on 623 (78\%) of them were found the simultaneous presence of wear facets of which 260 (81\%) on 317 and 256 (86.5\%) on 294 belonged to teeth of patients of group- 3 and -4 respectively. The finding of NCCLs and wear facets on same tooth

Table 2. Distribution of NCCLs and wear facets in examined teeth of subjects in 4 age groups.

\begin{tabular}{|c|c|c|c|c|c|c|c|c|c|c|c|c|}
\hline \multirow[t]{3}{*}{$\begin{array}{l}\text { Groups } \\
\text { patients }\end{array}$} & \multicolumn{3}{|c|}{$\begin{array}{l}\text { Group 1: } 27 \text { subjects } \\
\text { aged } 15 \text { - } 27 \text { years }\end{array}$} & \multicolumn{3}{|c|}{$\begin{array}{l}\text { Group 2: } 72 \text { subjects } \\
\text { aged } 28 \text { - } 42 \text { years }\end{array}$} & \multicolumn{3}{|c|}{$\begin{array}{l}\text { Group 3: } 129 \text { subjects } \\
\text { aged } 43 \text { - } 57 \text { years }\end{array}$} & \multicolumn{3}{|c|}{$\begin{array}{l}\text { Group 4: } 67 \text { subjects } \\
\text { aged } 58 \text { - } 75 \text { years }\end{array}$} \\
\hline & \multicolumn{3}{|c|}{ Teeth } & \multicolumn{3}{|c|}{ Teeth } & \multicolumn{3}{|c|}{ Teeth } & \multicolumn{3}{|c|}{ Teeth } \\
\hline & $\begin{array}{l}\text { Examined } \\
(\%)^{*}\end{array}$ & $\begin{array}{c}\text { NCCLs } \\
(\%)^{+}\end{array}$ & $\begin{array}{l}\text { WF } \\
\text { NCCLs } \\
(\%) \S\end{array}$ & $\begin{array}{l}\text { Examined } \\
(\%)^{*}\end{array}$ & $\begin{array}{c}\text { NCCLs } \\
(\%)^{+}\end{array}$ & $\begin{array}{l}\text { WF } \\
\text { NCCLs } \\
(\%) \S\end{array}$ & $\begin{array}{l}\text { Examined } \\
(\%)^{*}\end{array}$ & $\begin{array}{l}\text { NCCLs } \\
(\%)^{+}\end{array}$ & $\begin{array}{l}\text { WF } \\
\text { NCCLs } \\
(\%) \S\end{array}$ & $\begin{array}{l}\text { Examined } \\
(\%)^{*}\end{array}$ & $\begin{array}{l}\text { NCCLs } \\
(\%)^{+}\end{array}$ & $\begin{array}{c}\text { WF } \\
\text { NCCLs } \\
(\%) \S\end{array}$ \\
\hline $\begin{array}{l}\text { Maxillary } \\
\text { incisors }\end{array}$ & $\begin{array}{l}105 \\
(11)\end{array}$ & $\begin{array}{c}2 \\
(2)\end{array}$ & 0 & $\begin{array}{l}241 \\
(25)\end{array}$ & $\begin{array}{l}20 \\
(8)\end{array}$ & $\begin{array}{c}11 \\
(55)\end{array}$ & $\begin{array}{l}434 \\
(45)\end{array}$ & $\begin{array}{c}43 \\
(10)\end{array}$ & $\begin{array}{c}36 \\
(84)\end{array}$ & $\begin{array}{l}186 \\
(19)\end{array}$ & 35 (19) & $\begin{array}{c}31 \\
(89)\end{array}$ \\
\hline $\begin{array}{l}\text { Mandibular } \\
\text { incisors }\end{array}$ & $\begin{array}{l}103 \\
(11)\end{array}$ & $\begin{array}{c}3 \\
(3)\end{array}$ & $\begin{array}{c}1 \\
(33)\end{array}$ & $\begin{array}{l}246 \\
(25)\end{array}$ & $\begin{array}{c}24 \\
(10)\end{array}$ & $\begin{array}{c}14 \\
(58)\end{array}$ & $\begin{array}{l}427 \\
(44)\end{array}$ & $\begin{array}{c}56 \\
(13)\end{array}$ & $\begin{array}{c}47 \\
(84)\end{array}$ & $\begin{array}{l}179 \\
(18)\end{array}$ & $38(21)$ & $\begin{array}{l}33 \\
(87)\end{array}$ \\
\hline $\begin{array}{l}\text { Maxillary } \\
\text { canines }\end{array}$ & $\begin{array}{c}51 \\
(10)\end{array}$ & $\begin{array}{c}3 \\
(6)\end{array}$ & $\begin{array}{c}1 \\
(33)\end{array}$ & $\begin{array}{l}121 \\
(25)\end{array}$ & $\begin{array}{c}19 \\
(18)\end{array}$ & $10(53)$ & $\begin{array}{l}231 \\
(49)\end{array}$ & $\begin{array}{c}37 \\
(16)\end{array}$ & $\begin{array}{c}31 \\
(84)\end{array}$ & $\begin{array}{c}93 \\
(19)\end{array}$ & $25(27)$ & $\begin{array}{l}22 \\
(88)\end{array}$ \\
\hline $\begin{array}{l}\text { Mandibular } \\
\text { canines }\end{array}$ & $\begin{array}{c}52 \\
(11)\end{array}$ & $\begin{array}{c}3 \\
(6)\end{array}$ & 0 & $\begin{array}{l}123 \\
(24)\end{array}$ & $\begin{array}{c}22 \\
(18)\end{array}$ & $13(59)$ & $\begin{array}{l}227 \\
(46)\end{array}$ & $\begin{array}{c}31 \\
(14)\end{array}$ & $26(81)$ & $\begin{array}{c}91 \\
(19)\end{array}$ & $21(23)$ & $17(81)$ \\
\hline $\begin{array}{l}\text { Maxillary } \\
\text { premolars }\end{array}$ & $\begin{array}{l}102 \\
(10)\end{array}$ & $\begin{array}{c}2 \\
(2)\end{array}$ & 0 & $\begin{array}{l}241 \\
(25)\end{array}$ & $\begin{array}{c}33 \\
(14)\end{array}$ & $22(67)$ & $\begin{array}{l}456 \\
(46)\end{array}$ & $\begin{array}{c}47 \\
(10)\end{array}$ & 39 (83) & $\begin{array}{l}181 \\
(19)\end{array}$ & $57(32)$ & 51 (89) \\
\hline $\begin{array}{l}\text { Mandibular } \\
\text { premolars }\end{array}$ & $\begin{array}{l}104 \\
(11)\end{array}$ & $\begin{array}{c}3 \\
(3)\end{array}$ & $\begin{array}{c}1 \\
(33)\end{array}$ & $\begin{array}{l}237 \\
(25)\end{array}$ & $\begin{array}{c}27 \\
(11)\end{array}$ & $19(70)$ & $\begin{array}{l}447 \\
(47)\end{array}$ & $\begin{array}{c}43 \\
(10)\end{array}$ & 37 (86) & $\begin{array}{l}173 \\
(18)\end{array}$ & $45(26)$ & $41(91)$ \\
\hline $\begin{array}{c}\text { Maxillary } \\
\text { Molars }\end{array}$ & $\begin{array}{c}95 \\
(10)\end{array}$ & 0 & 0 & $\begin{array}{l}227 \\
(26)\end{array}$ & $\begin{array}{l}12 \\
(5)\end{array}$ & $\begin{array}{c}7 \\
(52)\end{array}$ & $\begin{array}{l}397 \\
(45)\end{array}$ & $\begin{array}{l}31 \\
(8)\end{array}$ & $21(68)$ & $\begin{array}{l}168 \\
(19)\end{array}$ & $42(29)$ & $36(86)$ \\
\hline $\begin{array}{l}\text { Mandibular } \\
\text { molars }\end{array}$ & $\begin{array}{c}98 \\
(11)\end{array}$ & $\begin{array}{c}2 \\
(2)\end{array}$ & 0 & $\begin{array}{l}231 \\
(26)\end{array}$ & $\begin{array}{l}15 \\
(7)\end{array}$ & $\begin{array}{c}8 \\
(53)\end{array}$ & $\begin{array}{l}391 \\
(44)\end{array}$ & $\begin{array}{l}29 \\
(7)\end{array}$ & 23 (79) & $\begin{array}{l}171 \\
(19)\end{array}$ & $31(18)$ & $25(81)$ \\
\hline T Test & \multicolumn{4}{|c|}{$\mathrm{p}=0.0002$} & \multicolumn{2}{|c|}{$p=0.006$} & \multicolumn{4}{|c|}{$p=0.06$} & \multicolumn{2}{|c|}{$\mathrm{p}=0.20$} \\
\hline Total teeth & 710 & 18 & 3 & 1667 & 172 & 104 & 3010 & 317 & 260 & 1242 & 294 & 256 \\
\hline $\begin{array}{c}\text { Median } \\
\text { percentage }\end{array}$ & 10.6 & 3 & 12.4 & 25 & 11.4 & 58.4 & 45.8 & 11 & 81 & 18.7 & 24.4 & 86.5 \\
\hline
\end{tabular}

*Percentage of teeth examined in each group; +Percentage of NCCLs on examined teeth for each group; §Percentage of wear facets (WF) on teeth with NCCLs. 
Table 3. Prevalence of $\mathrm{NCCL}_{\mathrm{S}}$ and wear facets in the population study.

\begin{tabular}{cccc}
\hline Teeth & $\begin{array}{c}\text { With wear facets } \\
\mathrm{n} \text { [median] (\%) }\end{array}$ & $\begin{array}{c}\text { No wear facets } \\
\mathrm{n} \text { [median] (\%) }\end{array}$ & Teeth examined \\
\hline With NCCLs & $623[2.1](78)$ & $178[0.60](22)$ & $\mathbf{8 0 1}$ \\
No NCCLs & $138[0.8](2.4)$ & $5591[18.95](96)$ & $\mathbf{5 8 2 8}$ \\
Total teeth examined & $\mathbf{7 6 1}$ & $\mathbf{5 7 6 9}$ & $\mathbf{6 6 2 9}$ \\
Statistical analysis & Chi square $=2908 ; \mathrm{df}=1 ; \mathrm{p}<0.0001$ & \\
\hline
\end{tabular}

[] Median of affected or unaffected teeth per subject with NCCLs; () Percentage of affected or unaffected teeth per total examined teeth.

increases the hypothesis of responsibility of occlusal stress in the pathogenesis of V-shaped NCCLs. The more findings of NCCLs and of wear facets found in the teeth of group-3 and -4 could indicate a more protracted exposure to the etiological stress factors compared with lower findings for teeth of younger patients in group-1 (12.4\% with $\mathrm{p}<0.0002)$ and in group-2 $(58.4 \%$ with $\mathrm{p}<0.006)$. These results together with the analysis of data from Table 3, clearly show the positive correlation between the presence of NCCLs and the presence of wear facets.

The outcomes of this study are in agreement with studies of Francisconi et al. (2009), of Pegoraro et al. (2005), of Machado NA et al. (2007) and of Takehara J et al. (2008) on etiological responsibility of occlusal forces to causing the V-shaped NCCLs (abfraction) [13]-[16].

We agree that the occlusal stress and tooth flexure could play a significant role in the etiopathogenesis of NCCLs. No single mechanism (abrasion, erosion, and abfraction) is adequate to explain all occurrences of clinical pictures of NCCLs, but a variable combination of all potential factors, operating at different levels and sometime the abrafction could represent the causative primum movens for NCCLs [17]. It has not been clearly identified if one process is more responsible for lesion initiation or for its progression, or vice versa. Initiation of breakdown by one process can make the tooth more susceptible to damage by the other processes, perhaps in a synergistic manner. Subsequently, one factor might predominate for the progression leading to the varied morphological presentations [18]. Ruling out from study all patients with a history of tooth abrasion or erosion, the discovery of NCCLs and of wear facets on the same tooth, should prompt us to considering occlusal stress as the main cause. Clinical evidence would suggest, for these cases, that the primary etiologic factor of angled, V-, or wedgeshaped cervical lesions is the tensile stress from masticatory and parafunctional habits causing tooth flexure and that local factors may play a secondary role in the dissolution of tooth structure intervening in change of shape of /lesions. Although there is no clear evidence about how the different forms of NCCLs may relate to one another, one could postulate that they reflect different stages of progression of the lesion [19].

We have observed a more incidence of NCCLs in subjects without any malocclusion but with flat occlusion and maximal interarch tooth contact in the centric occlusal function. Excursive tooth contacts can cause considerable tensile and shearing forces, especially if there are occlusal interferences. Indirect evidence is provided by the finding that bruxers have a greater incidence of NCCLs than nonbruxers. The finding of 138 teeth with wear facets without NCCLs but with a periodontal tissue not perfectly sound, might be related to the fact that forces of occlusal stress could have caused teeth migration, limiting or avoiding the break of dental tissue at the cement-enamel junction.

It would be desirable to repeat this study on a larger population as would be useful and program a prospective multicenter clinical trial based on the evaluation in time of the evolutionary behavior of the NCCLS after correction of factors of occlusal stress.

\section{Conclusion}

Erosion and abrasion have been widely reported as the causes of NCCLs. Recently, the tooth flexure has been proposal as additional or initial etiological factor in the formation of these lesions generating renewed interests in the pathogenesis of the noncarious loss of cervical tooth substance [20]. In fact, it is not always possible to find from the history of patients with NCCLs any over-brushing habit or food custom or pathologies that can be related to teeth cervical lesions. In these cases, a careful occlusal analysis to find a possible occlusal stress responsibility should be considered. The restoration or periodontal surgery with connective graft of NCCLs have to be considered parts of a therapy program more complex where the largest component must be targeted to the 
correction of occlusal stress eliminating parafunctions, suggesting soft bite and requiring psychotherapy sessions.

\section{References}

[1] Nguyen, C., Ranjitkar, S., Kaidonis, J.A. and Townsend, G.C. (2008) A Qualitative Assessment of Non-Carious Cervical Lesions in Extracted Human Teeth. Australian Dental Journal, 53, 46-51. http://dx.doi.org/10.1111/j.1834-7819.2007.00009.x

[2] Bartlett, D.W. and Shah, P. (2006) A Critical Review of Non-Carious Cervical (Wear) Lesions and the Role of Abfraction, Erosion, and Abrasion. Journal of Dental Research, 85, 306-312. http://dx.doi.org/10.1177/154405910608500405

[3] Lussi, A., Hellwig, E., Zero, D. and Jaeggi, T. (2006) Erosive Tooth Wear: Diagnosis, Risk Factors and Prevention. American Journal of Dentistry, 19, 319-325.

[4] Levitch, L.C., Bader, J.D., Shugars, D.A. and Heymann, H.O. (1994) Non-Carious Cervical Lesions. Journal of Dentistry, 22, 195-207. http://dx.doi.org/10.1016/0300-5712(94)90107-4

[5] Borcic, J., Anic, I., Urek, M.M. and Ferreri, S. ( 2004) The Prevalence of Non-Carious Cervical Lesions in Permanent Dentition. Journal of Oral Rehabilitation, 31, 117-123. http://dx.doi.org/10.1046/j.0305-182X.2003.01223.x

[6] Sognnaes, R.F., Wolcott, R.B., Xhonga, F.A. (1972) Dental Erosion I. Erosion-Like Patterns Occurring in Association with Other Dental Conditions. The Journal of the American Dental Association, 84, 571-576. http://dx.doi.org/10.14219/jada.archive.1972.0116

[7] Lee, W.C. and Eakle, W.S. (1984) Possible Role of Tensile Stress in the Etiology of Cervical Erosive Lesions of Teeth. Journal of Prosthetic Dentistry, 52, 374-380. http://dx.doi.org/10.1016/0022-3913(84)90448-7

[8] Oginni, A.O., Olusile, A.O. and Udoye, CI. (2003) Non-Carious Cervical Lesions in a Nigerian Population: Abrasion or Abfraction? International Dental Journal, 53, 275-279. http://dx.doi.org/10.1111/j.1875-595X.2003.tb00759.X

[9] Burke, F.J., Whitehead, S.A. and McCaughey, A.D. (1995) Contemporary Concepts in the Pathogenesis of the Class V Non-Carious Lesion. Dental Update, 22, 28-32.

[10] Grippo, J.O. (1991) Abfractions: A New Classification of Hard Tissue Lesions of Teeth. Journal of Esthetic and Restorative Dentistry, 3, 14-19. http://dx.doi.org/10.1111/j.1708-8240.1991.tb00799.x

[11] Jakupovic, S., Cerjakovic, E., Topcic, A., Ajanovic, M., Prcic, A.K. and Vukovic, A. (2014) Analysis of the Abfraction Lesions Formation Mechanism by the Finite Element Method. Acta Informatica Medica, 22, 241-245. http://dx.doi.org/10.5455/aim.2014.22.241-245

[12] Shetty, S.M., Shetty, R.G., Mattigatti, S., Managoli, N.A., Rairam, S.G. and Patil, AM. (2013) No Carious Cervical Lesions: Abfraction. Journal of International Oral Health, 5, 143-146.

[13] Francisconi, L.F., Graeff, M.S., Lde, M., Franco, E.B., Mondelli, R.F., Francisconi, P.A. and Pereira, J.C. (2009) The Effects of Occlusal Loading on the Margins of Cervical Restorations. Journal of the American Dental Association, 140, 1275-1282. http://dx.doi.org/10.14219/jada.archive.2009.0051

[14] Pegoraro, L.F., Scolaro, J.M., Conti, P.C., Telles, D. and Pegoraro, T.A. (2005) Noncarious Cervical Lesions in Adults: Prevalence and Occlusal Aspects. Journal of the American Dental Association, 136, 1694-1700. http://dx.doi.org/10.14219/jada.archive.2005.0113

[15] Machado, N.A., Fonseca, R.B., Branco, C.A., Barbosa, G.A., Neto, A.J.F. and Soares, C.J. (2007) Dental Wear Caused by Association between Bruxism and Gastroesophageal Reflux Disease: A Rehabilitation Report. Journal of Applied Oral Science, 15, 327-333. http://dx.doi.org/10.1590/S1678-77572007000400016

[16] Takehara, J., Takano, T., Akhter, R. and Morita, M. (2008) Correlations of Noncarious Cervical Lesions and Occlusal Factors Determined by Using Pressure-Detecting Sheet. Journal of Dentistry, 36, 774-779. http://dx.doi.org/10.1016/j.jdent.2008.05.009

[17] Sarode, G.S. and Sarode, S.C. (2013) Abfraction: A Review. Journal of Oral and Maxillofacial Pathology, 17, 222227. http://dx.doi.org/10.4103/0973-029X.119788

[18] Shellis, R.P. and Addy, M. (2014) The Interactions between Attrition, Abrasion and Erosion in Tooth Wear. Monographs in Oral Science, 25, 32-45. http://dx.doi.org/10.1159/000359936

[19] Grippo, J.O., Simring, M. and Schreiner, S. (2004) Attrition, Abrasion, Corrosion and Abfraction Revisited: A New Perspective on Tooth Surface Lesions. Journal of the American Dental Association, 135, 1109-1118. http://dx.doi.org/10.14219/jada.archive.2004.0369

[20] Tsiggos, N., Tortopidis, D., Hatzikyriakos, A. and Menexes, G. (2008) Association between Self-Reported Bruxism Activity and Occurrence of Dental Attrition, Abfraction, and Occlusal Pits on Natural Teeth. Journal of Prosthetic Dentistry, 100, 41-46. http://dx.doi.org/10.1016/S0022-3913(08)60135-3 